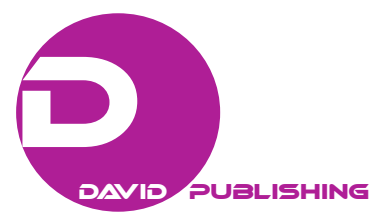

\title{
Censorship out Classroom Instruction in: A Case Study of Chinua Achebe's A Man of the People
}

\author{
Ada Uzoamaka Azodo \\ Indiana University Northwest, Gary, USA
}

\begin{abstract}
The benefits of classroom instruction far outweigh the censorship of reading materials placed in the school curriculum. This essay will advocate exposure and engagement of the youth in the classroom learning process for their wholesome education. Employing as a case study A Man of the People, Chinua Achebe's 1966 political fiction, this article will argue that censoring a controversial literary piece can deprive youth of a golden opportunity to learn about people and society with their own critical and creative abilities and arrive at good judgments by themselves and for themselves in an increasingly cross-cultural, complex, and complicated world.
\end{abstract}

Keywords: censorship, classroom education, literature, critical and creative thinking

\section{Introduction}

Censorship can harm youth education by preventing controversial materials from reaching the classroom. This essay will examine the shortcomings of suppressing controversial texts, and demonstrate the benefits of classroom exposure and engagement of students for a meaningful learning experience, through guided critical and creative thinking. Ronald T. La Conte's insightful essay, "Of Babies and Bath Water: A Closer Look at Censorship” (1968), presents the core issues at stake, and Vincent Ryan Ruggiero’s The Art of Thinking: A Guide to Critical and Creative Thought (2004) highlights the value of forming well-prepared students, through focus on eliciting mature and sensitive responses to conflicts, characters, and themes of a text, and garnering emotional and intellectual reaction through feelings, beliefs, and attitudes. This essay embraces Chinua Achebe's novel, A Man of the People, for three reasons: It has suffered censorship ${ }^{1}$; it is written in the first-person narrative, meaning that the characters' experiences are as close as can be to the author-narrator's sense of reality; and it ends in a surprising pathos, saving the authorial message from being lost in a bathos. This essay will conclude that teaching literature in the classroom will help to turn students into life-long learners, students able to get the best out of life by themselves and for themselves, rather than merely rely on opinions of other people ${ }^{2}$.

Ada Uzoamaka Azodo, Ph.D., scholar, researcher, Associate Faculty in the Humanities, College of Arts and Sciences, and Adjunct Professor of African, African American and African Diaspora Studies, Department of Minority Studies, and women's and gender studies, Women's and Gender Studies Program, Indiana University Northwest.

${ }^{1}$ Parents of an East African school system in the early 1990s objected to the references to sex in A Man of the People, alleging a probable or possible causal effect on youth behavior.

${ }^{2}$ Joshua Fetcher's list of seven benefits of reading literary fiction are the following: amplify your creativity; discover your hero or heroine; empathize; find yourself as you cultivate endurance and resilience; learn how to approach new obstacles; learn to have superior focus, and get your inner peace. Retrieved June 13, 2020, from https://www.lifehack.org/307436/7-benefits-reading-literary-fiction-you-may-not-know-2. 


\section{Theoretical Framework}

Ronald T. La Conte distinguishes between censorship from the outside and censorship from inside the school system in his essay “Of Babies and Bath Water: A Closer Look at Censorship.” In outside censorship, individuals and groups attack the School Board and the teachers about their choice of works on the classroom reading list. Controversial texts are discussed and removed, even though they may be allowed to remain accessible to students in the school and community libraries. So, outside censorship challenges the right of the school system to decide the texts to which students are exposed, and contests their right to establish curricular without input and opposition from the public. These never-ending public shows, La Conte opines, are often dramatic, complete with School Board meetings, questionnaires sent home to parents, Parent-Teacher Association (PTA) meetings, public meetings, and press coverage. Books that have been taught for decades suddenly are ordered off the reading list ${ }^{3}$. Inside censorship is even worse, partly because of its narrow view of the value of literature, and partly because in haste to display a false sense of virtue it manifests ignorance of the purpose of literature. Those that oppose a particular book, continues La Conte, "interpret their own fears and prejudices as manifestations of their desire to provide only the best for their students, and to shield them from the vulgar and the immoral” (1968, p. 4). Their arguments are listed as lack of maturity of the youth, causal effect of reading to behavior, controversial subjects that do not belong in the classroom, and community reaction to unwholesome texts.

In response to these arguments, La Conte counters that it is the school's responsibility to provide the right type of text for the students when they are ready, with the right teaching principle well applied to fit the text to the students. Moreover, teachers must not be blind to the fact that youth encounter so-called "adult subjects every day of their lives outside the school”. Hence, the notion that youth lack understating of a book or that it is too "adult' for them is 'non sequitur'”. Second, on the assumption that reading has a causal effect on student behavior, La Conte counters that that is not necessarily true, adding that if one has to remove books for profane language, sexual references, allusions to crime and criminality, anti-social behavior, racism, etc., then no book would survive in the curriculum in all the disciplines. Third, on the theory that anything controversial does not belong in the school, but to the home and church-dress, politics, sex, religion, prayer, etc., La Conte argues that literature should not be one of them, note taken of the literature teacher's job and the subject of literature to deal with books that talk about sex, religion, philosophy, and other themes innumerable to mention, primarily as works of art and craftsmanship before they are judged for their content. Fourth, on the notion that controversial content could precipitate unfavorable reaction from parents and the community at large, La Conte opines that teachers should be ready to defend their choices of texts in the curriculum whenever attacked, "If we construct a curriculum based on fears rather than on conviction, if we subscribe to the concept of 'anticipatory restraint,' we are essentially admitting our own incompetence. We are proclaiming to all our inability to defend what we do" (1968, p. 5).

La Conte concludes that many authors and texts are left out of the curriculum, due to fears both from outside and inside the school system. In their place are positioned the classics, but even then they are those that meet the expectations of making zero allusions to sex. Modern literature is left out, thereby leaving students ill-prepared to

\footnotetext{
3 John Blosser, “Alaska School Board Throws Five Classic Books out of School”, recently reported in Anchorage Daily News that The Matanuska-Susitna School Board, USA, with a 5-2 vote, banned five literary classics from being taught in the classroom: "Invisible Man” by Ralph Ellison (for bad language, rape and incest); “Catch-22” by Joseph Heller (for "racial slurs, misogyny, racist attitudes, and violence and war against women”); “The Things They Carried” by Tim O’Brien (for profanity and sexual references); "I Know Why the Caged Bird Sings” by Maya Angelou (for Angelou's description of sexual abuse she suffered in childhood), and “the Great Gatsby” by F. Scott Fitzgerald (for language and sexual references). Retrieved date, April 28, 2020, 11:03 PM.
} 
proceed to university and still ignorant of their humanity in many ways as they grow up. Students should be exposed to all kinds of readings in the classroom and encouraged to engage with them for their own wholesomeness, Furthermore, the ultimate teaching goal ought to be to "seek to expand, through reading, the student's insight into the human situation in all its aspects, to increase his (and her; our own addition) awareness of the world in which he/she lives and the people who inhabit it. We hope that he/she will leave our classrooms able, for the rest of his/her life, to read, with understanding and perception and delight” (Ronald, 1968, p. 10).

\section{A Case Study of A Man of the People}

\section{Synopsis of A Man of the People}

Mr. Odili Samalu, a school teacher in a private village secondary school, the Anata Grammar School, is the first-person narrator of the novel, A Man of the People. Odili receives a letter from Chief Micah Nanga, his former teacher and mentor in standard three, now the Minister of Culture of their unnamed country ${ }^{4}$, to meet him at the school during his campaign tour for his reelection. After they reconnect over memories of past years, the Minister invites him to visit him in his residence in the capital city of Bori, and floats an idea to help him proceed overseas for postgraduate studies. In Bori, though, mentor and ward fall out, when Odili's eyes are opened to the enormity of social ills in the country: corruption in high places in government, waste of resources meant for services to the people, ignorance of the leaders of the nation, and cynicism of the common people and their leaders. The immediate cause of their split is that Chief Nanga double-crosses Odili in the Minister's quarters and sleeps with his girlfriend, Elsie with whom he planned to spend a voluptuous night after Chief Nanga's speech on art and culture at the Writers' Society event. Personally wounded and challenged, Odili decides to get even; he will seduce Chief Nanga’s fiancée and soon-to-become second wife, Edna, and contest his position by joining an opposition party. Unfortunately for idealistic Odili, plagued by a tripartite problem he cannot get through the cynicism of the people that have lost faith in democracy, nor successfully maneuver around the moral bankruptcy of his own party colleagues, nor have opportunity to end his campaign without hurting his family and fellow villagers. Utterly frustrated, Odili infiltrates his opponent Chief Nanga's political rally, is recognized as the enemy and is beaten to a pulp, and he ends up in the hospital with massive head injuries. In the mayhem that ensues Max, his friend, is murdered by thugs before his fiancée, Eunice, who avenges him by shooting his killer dead. Nanga is reelected. The budding love between Odili and Edna blossoms as Edna cares for him in the hospital. Odili drops his quest for revenge against Nanga and woos Edna to win her heart. Both their families, initially stumbling blocks for their union, support their relationship. Odili pays off Edna's debt to Chief Nanga and they get married. But, much to Odili's incomprehension, the same cynical common people rise up in a revolution against Nanga, the day after election they just decided by their votes ${ }^{5}$. Finally, the people are speaking out against the endemic corruption and leadership in the country. Following the general unrest, a coup d'état topples the new government (Achebe, 1967, p. 148). Odili pursues his new life with Edna with a peaceful heart, and exonerates himself by saying that he failed but tried to do his best.

\footnotetext{
${ }^{4}$ This assertion is made with tongue in cheek, for there are many, many words, proverbs that are recast in English, allusions, and popular expressions of the day that point to Nigeria as the setting.

5 "Verisimilitude” means "similar”. Language philosopher Steve Neale distinguishes two types: cultural (meaning plausibility of the fictional work within the cultural and/or historical context of the real world, outside of the work) and generic (meaning plausibility of a fictional work within the bounds of its own genre). Wikipedia. Upon the release of A Man of the People in 1966, the Nigerian poet and playwright John Pepper Clark lauded its verisimilitude, saying, "Chinua, I know you are a prophet. Everything in this book has happened except a military coup!” Later, on January 15, 1967, five majors of the Nigerian army staged Nigeria's first coup d'état, forcing Chinua Achebe to flee for his life.
} 


\section{A Man of the People Under Censorship}

In this sub-section, we shall be creative in determining the possible negative impact of censorship of $A$ Man of the People. According to Vincent Ryan Ruggiero (2004), "Being creative means combining knowledge and imagination .... Creativity does involve a willingness to break away from established patterns and try new directions, but it does not mean being different for the sake of being different or an exercise in self-indulgence. It is as much a mistake to ignore the accumulated knowledge of the past as it is to be limited by it” (p. 24).

\section{Excerpts}

I don't mean the white girls—you can have those out here nowadays—but quite small things. (Achebe, 1967, p. 17) (Elsie) ... the only girl I met and slept with the same day -in fact within an hour. (Achebe, 1967, p. 24)

Irre (Irresponsible) broke the Unbreakable and showed evidence by coming out sweating and holding up a condom bloated with his disgusting seed. (Achebe, 1967, p. 25)

Mrs. Nanga whose Christian name I hadn’t even known until now seemed less happy. She said "Hallo, hallo," and almost immediately withdrew, her frock caught in the parting of her buttocks. (Achebe, 1967, p. 44)

Here you have John speaking high monologue to me while his wife seems ready, judging by the look in her eyes, to drag Chief Nanga off to bed in broad daylight. (Achebe, 1967, p. 46)

After all, I told myself, Chief Nanga who was barely literate was probably going to sleep with her that night. (Achebe, 1967, p. 49)

Apparently Jean had noticed while we talked after dinner that I was shaking my legs, which meant that I wanted so badly to go to bed with some woman. Was it me or Elsie you wanted? (Achebe, 1967, p. 53)

Sex means more to a woman than to a man. (Achebe, 1967, p. 53)

As for Elsie I should have known that she was a common harlot and the less said about her the better. Kabu-Kabu (good-time girl). (Achebe, 1967, p. 72)

The best (story) I thought was about the young married woman who never took her brassière off. It was not until after many encounters that Chief Nanga managed to extract from her that her husband (apparently a very jealous man) had put some juju on her breasts to scare her into faithfulness; the idea being presumably that she would not dare to expose that part of her to another man much less other parts. (Achebe, 1967, p. 60)

I didn't listen much to Chief Nanga's speech. When Elsie and I were not whispering into each other's ears I was thinking about the night ... (Achebe, 1967, p. 65)

It was already past half-past ten. This stung me into activity again. I hadn't thought it was so late. I rushed into the sitting-room and made to bound up the stairs when I heard as from a great distance Elsie deliriously screaming my name (...). I trudged up the stairs in the incredible delusion that Elsie was calling me to come and save her from her ravisher. But when I got to the door a strong revulsion and hatred swept over me and I turned sharply away and went down the stairs for the last time. (Achebe, 1967, p. 71)

What mattered was that a man had treated me as no man had a right to treat another-not even if he was master and the other slave; and my manhood required that I make him pay for his insult in full measure. In flesh and blood terms I realized that I must go back, seek out Nanga's intended parlour-wife and give her the works, good and proper. (Achebe, 1967, p. 77)

It (sex) takes place "inside” her. The man uses a mere projection of himself. (Achebe, 1967, p. 54)

I was wondering whether I could see you again. /Do you want to? /Sure. /Why not? Let me call you tomorrow. (Achebe, 1967, p. 56)

Clearly, there are so-called "dirty words" in the novel, such as sex, harlot, slut, condom, one-night stand, buttock, abuse, infidelity, kabu-kabu, goodtime girls, and "fuck". But, it would be presumptuous to think that teenage students will get exposed to any or all of the above for the first time in reading A Man of the People. Then, social reality is not immune to violence, given the contents of the daily news media. Moreover, proportionately speaking, the sporadic allusions to sex, profanity, and racism should not condemn the whole 
novel. These passages above are not what A Man of the People is all about, for sex is part and parcel of the life of a politician, and all human beings, for that matter. What is evident is that bad men in powerful positions in government use woman as playthings. Then, they manage to hold on to power even when the populace is aware of their unfitness for the positions they occupy, essentially because the people connive with the corrupt practices. The idealists lose out, because they philosophize, moralize, and then sit back and do nothing tangible. Even on rare occasions when they react, they employ the worst kinds of tactics, due to ignorance of the true reality of things in their society, lack of ability, and courage ${ }^{6}$ (Achebe, 1967, p. 11).

On the other hand, through classroom study students will see how rampant gender abuse, sex-trafficking, and social injustice are in our world, how patriarchy runs sway, and misogynistic men use disadvantaged girls and women as sex objects and play things. In the classroom, the teacher can be of tremendous help to students as they learn human behavior through the characters and their actions. In the words of Ronald La Conte (1968),

We need to expand, through reading, the student's insight into the human situation in all its aspects, to increase his awareness of the world in which he lives and the people who inhabit it. We hope that he will leave our classrooms able, for the rest of his life, to read with understanding and perception and delight. (p. 10)

La Conte (1968) continues on the role of the teacher:

The teacher who substitutes for these goals the peddling of moral lessons in literary form, who settles for exposure instead of insight, is not only guilty of dishonest teaching but also of the most pernicious form of censorship. For this kind of teaching goes far beyond the mere denial of access to particular books; it attacks both the desire and the ability to respond to literature. Through continual contact with such an attitude towards literature, students come to look on books as repositories of cleverly concealed moral advice. At best, they become message hunters, studying each book they read to discover its "meaning” or moral. At worst, discouraged by the inconsistency between what the teacher finds in the books and what they themselves find in the work, they decide that literature is foolish or trivial, hardly worth much time or effort. (p. 10)

The teacher is called upon to make a complicated and complex moral judgment to teach in the true sense

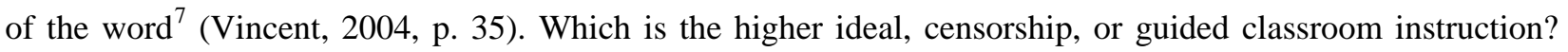
Where lies the critic's most serious or first obligation? To answer these questions appropriately, one must weigh the benefits of censorship against the value of classroom teaching, the idea being to establish that a good literature teacher should be able to engage the students through focus on the more enduring qualities, the author's art and craftsmanship rather than the textual frivolities and the inconsequential. Therefore, the issue is over the rightness or wrongness of teaching a controversial text in the classroom. It is not a problem about the cohabitation of evil and good in the world, for that is a given.

\section{A Man of the People in the Classroom}

R. F. Beauchamp (1968) stated clearly the value of literature in humanizing individuals and society in The Structure of Literature: A Guide for Teachers:

Most teachers view literature study as a necessary and useful tool through which students are helped to realize their humanity. What we most desire is to produce students who are able to respond to characters, problems, and themes in a

\footnotetext{
${ }^{6}$ Odili muses: "Somehow I found myself admiring the man for his lack of modesty. For what is modesty but inverted pride? We all think we are first-class people. Modesty forbids us from saying so (...).

7 To achieve depth in your examination of moral issues and wisdom in your judgment, you must deal effectively with complexities. The presence of two or more conflicting obligations or ideals creates complexity. So does the likelihood of multiple consequences, some beneficial and some harmful.
} 
sensitive and mature manner. We feel amply rewarded for our efforts when students demonstrate through their recitations and written papers that they are in fact responding emotionally and intellectually to literature .... Classroom study of a literary work should help students to understand human motivation. It should help them to understand how attitudes, feelings, and beliefs govern what fictional characters do. These understandings help students to determine who they are, what they are, and why they are. (pp. viii-ix)

To wit, Chinua Achebe manifests three ways of knowing in A Man of the People: personal experience, detailed observation, and skillful reporting of materials observed. There is constant interaction of character, theme, and style in this novel. Students must know that, and they must also be told that the role a character plays influences the way she/he behaves, and that under pressure to conform in a group or crowd, a character might even contradict his/her own judgments and perceptions ${ }^{8}$ (Vincent, 2004, p. 122). Hence, evaluation of a character should be a value judgment, as an exception, not merely according to whether the character is a hero, a heroine, or a villain. Through the examination of character, theme, and style in A Man of the People, the student gains insight into not only the illustrious author's art and craftsmanship, but also the significance of his contribution to (re)shaping society.

\section{Character}

Chinua Achebe upfront acquaints the readers of A Man of the People with his dilemma as he tries to accomplish characterization without giving away too much at a time (Achebe, 1967, p. 24). Still, he superbly fields everlasting fictional characters with individual names, plausible motivations, engaging in specific actions in their own historic time and place.

Two characters, Chief the Honourable Micah A. Nanga, M. P. (Member of Parliament) and Minister of Culture, and Mr. Odili Samalu, high school teacher for eighteen months after earning a university degree, are locked in a deadly conflict for the position of Minister of Culture and for the heart of a young and beautiful lady, Miss Edna Odo. The three characters are introduced together in the early pages of the novel with utmost economy of means ${ }^{9}$ (Achebe, 1967, p. 12). As the novel plot unfurls, their conflict will expose the depth of corruption in their country, leading to the common people being emboldened enough to challenge their corrupt and morally bankrupt leaders in a revolution that will precipitate an army take-over in a coup d'état.

Chief Nanga, the "man of the people" of the eponymous title, a true reflection and a typical representative of their society, is the "protagonist." Nonetheless, he cannot be a hero, for he is neither deeply admirable, beyond his handsome looks, nor is he a model to emulate for anyone who cares about decency, discipline, morality, respect, integrity, and empathy. The narrative voice describes him as "an Honourable Thief"10 (Achebe, 1967, p. 139). A static character, neither dynamic nor kinetic, he remains from start to finish a corrupt and ignorant Minister of Culture, by far a wrong choice of leader for his people ${ }^{11}$.

Odili Samalu, somewhat out of touch with his people, is the "antagonist." Through him, the student can experience the effect of boldness on performance. At the climax of the novel, he narrowly escapes death at the

\footnotetext{
${ }^{8}$ On two separate occasions, two well-known psychological experiments, proved that: (1) people who find their power enjoyable were reluctant to relinquish it; and (2) under group pressure an isolated respondent would yield and give the answer so as to conform to the group.

9 I remember that at that point the beautiful girl in the Minister's party turned around on her chair to look at me. My eyes met hers and she quickly turned around again. I think the Minister noticed it.

${ }^{10}$ (....) the great man they had come to hear with their drums and dancing was "an Honourable Thief”. But of course they knew that already. No single man or woman there that afternoon was stranger to that news-not even the innocent-looking convent girl on the dais.

11 A hackneyed expression would say that "power corrupts and absolute power corrupts absolutely.”
} 
hands of the protagonist's thugs. Like Chief Nanga, Odili represents a minority section of their society. But, unlike Chief Nanga, Odili is not corrupt, though corruptible to an extent. Of two dimensions in stature, like all stock characters, Odili is overemphasized as narrator and character. As a stereotype of the Western (read European- or American-trained) intellectual, Odili is distant from the citizenry ${ }^{12}$. He shows off the plausibility of narcissist politicians, such as Chief Nanga who ensures that only his voice is heard by the people and refuses to grant them space to consider any other face of reality ${ }^{13}$ (Achebe, 1967, p. 6). Nonetheless, Odili is not a villain, thanks to his intelligence and self-pride. His quest for revenge could be interpreted as a figment of his creative genius for problem solving ${ }^{14}$ (Vincent, 2004, p. 115), and his conflict with Chief Nanga as his struggle against the entire society. Yet, Odili's distorted views on sex, morality, women, politics, etc. can be bothersome to the informed reader. In his “elevated thoughts," according to him, his first night at Chief Nanga's official residence in Bori he revels in the opportunity to enjoy the luxury, albeit temporarily, refusing to criticize evil and corruption ${ }^{15}$ (Achebe, 1967, p. 37). Lucidly, he observes, "The trouble with our new nation as I saw it then lying on that bed was that none of us had been indoors long enough to be able to say, 'To hell with it.' We had all been in the rain together until yesterday. Then, a handful of us - the smart and the lucky and hardly ever the best - had scrambled for the one shelter our former rulers left, and had taken it over and barricaded themselves in” (Achebe, 1967, p. 37). As narrator, he moves the plot nicely and effortlessly along with several episodes of comic relief ${ }^{16}$. His fluid views and opinions of society and Chief Nanga are tremendously helpful in making the characters believable and the novel understandable ${ }^{17}$ (Achebe, 1967, pp. 6-16).

Edna Odo can be at once a major and minor character. She is complex and can surprise the student by her metamorphosis from a mere sex object and a thing in the service to Chief Nanga, a beautiful showpiece in his ministerial entourage at his political campaigns rallies into a friend and agent to Odili. Edna can make the student consider the effect of sacrifice in friendship and relationships ${ }^{18}$ (Achebe, 1967, p. 141). With her consent, Odili pays off Chief Nanga all his fifteen pounds of school fees and miscellaneous expenses on her. Then, Odili changes course, from seeking revenge against his rival to loving and honoring her with his body in marriage (Achebe, 1967, p. 148).

\footnotetext{
12 Stereotype of a narrow-minded intellectual trained in European-style education that does not work with his African society.

13 Chief Nanga addresses the people at his campaign rally: "From today we must watch and guard our hard-won freedom jealously. Never again must we entrust our destiny and the destiny of Africa to the hybrid class of Western-educated and snobbish intellectuals who will not hesitate to sell their mothers for a mess of pottage. ...

${ }^{14}$ An older woman living in an apartment devised a revenge strategy of jumping rope in the early hours of the morning to deal with a noisy neighbor upstairs. "What happened next proved Jean's idea to be even more creative than she had realized. In a few days, the woman knocked on Jean's door and explained sheepishly that Jena's jumping was keeping her awake. Jean seized the opportunity and said, "I'll tell you what: I'll stop jumping rope if you'll turn the stereo down." The woman agreed, and the problem was solved.

${ }^{15}$ I had to confess that if I were at that moment made a minister I would be most anxious to remain one forever. And maybe I should have thanked God that I wasn't. We ignore man's basic nature if we say, as some critics do, that because a man like Nanga had risen overnight from poverty and insignificance to his present opulence he could be persuaded without much trouble to give it up again and return to his original state.

${ }^{16}$ A Man of the People. Front Book cover. The New York Times speaks of the author's "considerable power (...) achieved through his fine sardonic sense of the comic."

17 See Instances of author-narrator's humor during Chief Nanga’s visit to Anata Grammar School to drum up campaign for his reelection.

${ }^{18}$ Edna rushed forward crying and tried to get between us but he pushed her aside so violently that she landed on her buttocks on the wooden platform. The roar of the crowd was now like a thick forest all around. By this time blows were falling as fast as rain on my head and body until something heavier than the rest seemed to split my skull. The last thing I remembered was seeing all the policemen turn around and walk quietly away.
} 
Clearly, the study of the major characters of A Man of the People, Chief Micah Nanga, Odili Samalu, Edna Odo, and all the other minor characters can help students cultivate their individuality and develop their innate capabilities for broadening their perspectives on life. The exposure in the classroom can mean acculturation to foreign cultures, rather than settlement into their culture as if they are the only race that exists and matters on earth, while harboring uncritically accepted norms as most of the people would do with received ideas and attitudes from people and institutions. This doing as everyone does and not questioning what their peers and leaders do is not the way to be a responsible citizen ${ }^{19}$ (Achebe, 1967, pp. 2-3). Rather than become sycophants of the high and mighty men in powerful positions, students can learn to sort out received ideas and attitudes, work out in their own minds their responsibility as citizens, the place of their leaders in government, and then decide which ideas and attitudes to adopt. Finally, characterization in this novel raises the important issue about who is the hero or heroine for young people to emulate, meaning, strong and progressive characters that live a life of example for their people. If the archetypal hero or heroine is the one who goes out and achieves great deeds for the group, then it is neither Chief Nanga nor Odili. On the contrary, that qualification goes to the martyred $\operatorname{Max}^{20}$ (Achebe, 1967, pp. 148-149). Eunice and Edna qualify as heroines and models for the youth, for both women prove to be strong, courageous, and progressive, fighting side by side with their men for a better future for individuals and the nation ${ }^{21}$ (Achebe, 1967, p. 148).

\section{Theme}

It is important to explain to students that all aspects or elements of A Man of the People contribute to its ultimate meaning or theme. Some of the major themes are love, sacrifice, freedom ${ }^{22}$ (Achebe, 1967, p. 77), gender equality, social justice, racism, and colonialism among others. Corrupt, immature, and mediocre politicians play around with the people's freedom. As a prototype of the corrupt man, Nanga is a mirror image of his ignorant and cynical people ${ }^{23}$ (Achebe, 1967, pp. 2-3). Odili complains, even louder than the first time, about the laissez faire attitude and culture of his people, their tendency to "eat and allow others to eat," at the risk of dooming the country for generations to come (Achebe, 1967, p. 145). Then, how could there be genuine "love" among the people and "sacrifice" for the nation amidst corruption in all fabrics of the society? Among the symbols of social decadence, social injustice and corruption are the big foreign cars, big houses in the cities versus the ordinary people's shacks in the villages, not to mention the slums of the dual city versus the rich areas in the capital city of Bori ${ }^{24}$. When the revolution finally strikes, the bewildered first-person narrative voice laments, "What I found distasteful however was the sudden, unashamed change of front among the very

\footnotetext{
${ }^{19}$ Odili stated, "I wished for a miracle, for a voice of thunder, to hush this ridiculous festival and tell the poor contemptible people one or two truths. But of course it would be quite useless. They were not only ignorant but cynical. Tell them that this man had used his position to enrich himself and they would ask you —as my father did—if you thought that a sensible man would spit out the juicy morsel that good fortune placed in his mouth."

20 "Max was a hero and martyr; and I propose to found a school—a new type of school, I hasten to add—in my village to his memory,” stated Odili.

${ }^{21}$ Regarding Eunice, the narrative voice confesses, "But their most touching gesture as far as I was concerned was to release Eunice from jail and pronounce Max a Hero of the Revolution.”

22 Odili stated, "That first night I not only heard of a new political party about to be born but got myself enrolled as a foundation member. Max and some of his friends having watched with deepening disillusion the use to which our hard-won freedom was being put by corrupt, mediocre politicians had decided to come together and launch the Common People's Convention."

23 "They were not only ignorant but cynical," Odili complains. "Tell them that this man had used his position to enrich himself and they would ask you — as my father did—if you thought that a sensible man would spit out the juicy morsel that good fortune placed in his mouth."

${ }^{24}$ John J. Macionis and Vincent N. Parrillo discuss the dual city of African capitals, marked by a stark difference between the rich areas where the nouveaux riches live and the downtrodden slums where the common people live in cities and urban life.
} 
people who had stood by and watched him (Max) die. (...) Overnight everyone began to shake their heads at the excesses of the last regime, at its graft, oppression and corrupt government”25 (Achebe, 1967, p. 149). Finally, they denounce Chief Simon I. Koko, the Honourable Minister for Overseas Training and the caricature and butt of the narrator's jokes ${ }^{26}$ (Achebe, 1967, p. 33-36) as a rogue:

Chief Koko in particular became a thief and a murderer, while the people who had led him on -in my opinion the real culprits—-took the legendary bath of the Hornbill and donned innocence. (p. 149)

From a gender perspective, illiteracy among women is counterproductive (Achebe, 1967, p. 134). The narrator infers that with higher education women can have a stronger voice and make better choices in their lives. He prefers strong women, like Eunice, and Edna after her metamorphosis, women who relate with their men as equals, women who understand that love and romance are beneficial when shared equitably. He criticizes women's subjugation, but does not endorse promiscuity, infidelity, and lust. Comparing the look of Mrs. Margaret Nanga soon after her marriage to Chief Nanga, when she was among the "acme of sophistication" and her sagging body years after maternity when her clothes get stuck in the parting of her buttocks - this is repeated twice in the novel—Odili makes it clear that women should take better care of their bodies and appearance (Achebe, 1967, p. 36). Age has nothing to do with this, for Mrs. Margaret Nanga could do better by herself by beefing up her sense of who she is and what she is (Achebe, 1967, p. 36). But, with only basic education and lacking in working skills her self-confidence also sags and she runs a risk of no longer pleasing her husband. Yet, studies have shown that appropriate exercises that strengthen the glutes and Kegel muscles of the pelvic floor can help women in their middle age get toned, look better, and be healthier.

Finally, slavery, colonialism, and racism mirror unequal power relations between nations and races and augur badly for the future, unless humankind institutionalizes equality of individuals before the law. Many of the cultural misunderstandings and superiority complex of the ex-colonials vis-à-vis the ex-colonized stem from slavery, colonialism, and racism. The condescending attitude to descendants of slaves has still not gone away even after four hundred years. And the dependency syndrome of the ex-colonized in their countries has not gone away either. These views are demonstrated during a meeting of Odili and some foreigners while he is visiting the Minister of Culture in Bori. At a dinner gathering, characters without proper names-a middle-aged British woman, a middle-aged American Negro, an old white British couple, an American white woman, and Jean and Odili-discuss art, gestures, and sculpture across cultures. As stereotypes, the views and opinions of the older people on race relations are fixed - the white foreigners use verbal force to entrench themselves as the authentic humans, owners of beautiful art, human rights, and lofty beliefs. Before the evening is over, all the shades of racism — ethnic, political, gender, and religious - play out between subtly hostile company pretending to have a peaceable interaction with one another. Above all, it is a power tussle between Odili, the African, and the foreigners. The awkward situation of the African American present is another twist to the whole race game; no one knows exactly how to identity him, as an African or as an American (Achebe, 1967, p. 52). Even the

\footnotetext{
${ }^{25}$ Compare with Argentinian Facundo Cabral, singer, composer, and on the incomprehensible habit of the masses to side with a wrong cause without thinking, saying: "My grandfather was a brave man, he was only afraid of idiots. I asked him why, and he answered: Because there are too many of them, and by being a majority they could even elect a president."

${ }^{26}$ A Man of the People (pp. 33-36), comically wails, wringing his hands with agony and fear visible all over him, as he rolls his eyes, and shouts "They have killed me (...). They have poisoned my coffee.” All this is because he unwittingly drank a cup of homemade coffee in place of his habitual foreign brew.
} 
adulterous sexual encounter later that evening between Odili and the American Jean, whose husband John is away from home to Abaka for a few days to preside over the grand opening of a new cement factory built with American capital, is nothing but a carry-over of black-white antagonism or war of slavery years (Achebe, 1967, Chapter 5, pp. 48-56).

Guided teaching of these intricate themes can help students to understand the differences among human beings in a shrinking global world, thanks to new technology, knowledge, travel, and work. Students will see how limited they are in having only the experience into which they were born, when they learn to think outside the box, and acquire skills and ability to relate with people from other races on their own terms. Indeed, A Man of the People can provide intercultural and international experiences to students from faraway lands. Students can also see that other people merit just as much dignity, integrity, and respect as they would accord themselves and other people in their immediate circles and environment.

\section{Style}

Several literary devices, not the least of which are, humor, flashback, imagery, suspense, letter, foreshadowing, telescoping, figurative language, satire, verisimilitude, realism, symbolism, tone, imagery (simile, metaphor, etc.), diction (dialogues, characters, and feelings), and point of view (first-person narrator [intimate and emotional]), relate the novel's story with more vigor and force that make the novel more meaningful for the reader. The teacher must point out the uses and values of these stylistic devices used by the narrator to make the novel story believable, without trampling on the reader's feelings, that themes go hand in hand with the style, and that language matches the motivations of the speaker that may speak in standard English, argot, pidgin, and vernacular as the situation demands.

Notice "stylistic subtlety" in the comparison and contrast of the festive mood at the beginning of A Man of the People, when the Ego Women's Party and the Hunters' Guild entertain a joyous crowd assembled to welcome Chief Nanga on campaign tour for his reelection, and the chaotic turn of events towards the end of the novel, when violence and bloodshed overrun the country, then some of Chief Nanga's thugs refuse to be disbanded, a revolution ensues, and a bloody coup-d'état takes place.

"Humor and wit" render vices ridiculous and comical, making the criticism for correcting social ills and instituting national remodeling more acceptable to the reader. With the use of irony, sarcasm, and satire, and sometimes direct authorial intervention in the dialogue, the narrative voice lucidly conveys, exposes, unveils, and interprets human experiences observed. There is, for example, the criticism of the people and society during the comic hiring interview of a new cook for the ministerial quarters. The bitter social criticism of ignorance, subordination of women under patriarchy, gender abuse of women and females as secondary citizens therein, fade away in smiles and laughter at human foibles ${ }^{27}$ (Achebe, 1967, pp. 46-47).

On Odili's return from Bori, a bystander explains to the first-person narrator the happenings in the village, since he was not there to observe them himself. There is "flash back" to when Josiah stole the blind man's stick to make juju to blind his customers, so that they buy more and more from his restaurant and bar, and so make him rich. The narrator's "tone” in asking to be informed is inquisitive and believable.

In treating "symbolism," the teacher should let the students know that concrete objects represent

\footnotetext{
${ }^{27}$ Odili summarizes the comical episode, stating the obvious. "We agreed with him but he lost the job because Chief Nanga preferred bitterleaf and egusi to chicken puri-whatever that was. But I must say the fellow had a point too. As long as a man confined himself to preparing foreign concoctions he could still maintain the comfortable illusion that he wasn't really doing such an unmanly thing as cooking."
} 
abstract ideas. "Hospital" in this novel can represent a shelter, a refuge, for in it, Odili gets the needed space to rethink his life and map out a new direction going forward after his showdown with Chief Nanga. "Cadillac" can symbolize at once opulence and decadence amidst the starvation of the common people. These are by no means conventional symbols, because they do not have a pre-established meaning attached to them. They are rather created or invented symbols in the context, with the meanings attributed or attributable to them in the novel.

With "name symbolism," the teacher has opportunity to teach about personal behavior, character, and the importance of making a good name. For William Shakespeare, character and good behavior are worth more than a name, name which for him was nothing more than merely a way to distinguish one thing or a person from another. However, in the play Romeo and Juliet, Juliet could care less whether Romeo was a Montague and she a Capulet; she loved him any way despite the hostility between the two families: "What's in a name? That which we call a rose/By any other name would smell as sweet." Chinua Achebe, for his part, ironically employs first name symbolism to denounce social ills, through naming some of his characters after Biblical or Hebrew antecedents. The corrupt Minister of Culture, Chief Micah Nanga, is not the Biblical prophet Micah, who denounced oppression and was angered by the conquest of Judah by Babylon. The rapacious businessman, Josiah, is not the Josiah who became King of Judah at eight years of age after his father was assassinated, and later carried out religious reforms for which he became famous. Hezekiah Samalu, though, was loved by friends and foes, much like the thirteenth King of Judah, Hezekiah, who found favor with God and was accorded fifteen extra years of life after a very serious illness could have killed him. Achebe's women also find favor with the narrator. Mrs. Margaret Nanga's behavior is close to that of the Biblical Margaret, Patron of expectant mothers, whose name means "Pearl." Edna, young and beautiful, approaches her biblical counterpart, the mother of Sarah in Tobit whose name meant "delight," "rejuvenation," "pleasure," or "youthfulness." Eunice, who fights the murderers of her fiancé, Max, stoically goes to jail, and is finally exonerated and freed, and comes close to the biblical woman without hypocrisy, who was good, and joyous in victory. Mrs. Eleanor John, who is named for historical Eleanor, shows her own brand of "brightness" in explaining the difficult position of a minister; with Achebe's tongue in his cheek about this, of course (Achebe, 1967, pp. 14-15). Then, the learned Barrister Mrs. Agnes Akilo, "She who must be obeyed,"28 according to Odili, presents a stern façade, like her Greek pure and holy counterpart, but is really cheap and ready to sleep with the next "big man" (Achebe, 1967, p. 49).

The power of "imagery" to render description concrete is captured in the Josiah-Azoge saga. Denouncing Josiah's rapaciousness in stealing a blind man's stick to make juju to become wealthy, the narrative voice states: "Some people's belly is like the earth. It is never so full that it will not take another corpse. God forbid;" "Josiah has taken away enough for the owner to notice (...). If anyone ever sees my feet in this shop again let him cut them off. Josiah has now removed enough for the owner to see.” Then, he concludes:

I thought much afterwards about that proverb, about the man taking things away until the owner at last notices. In the mouth of our people there was no greater condemnation. It was not just a simple question of a man's cup being full. A man's cup might be full and none be (sic!) the wiser. But here the owner knew, and the owner, I discovered, is the will of

\footnotetext{
${ }^{28}$ This is a reference to the famous novel, She, by the South African Rider Haggard.
} 
the whole people. ${ }^{29}$ (Achebe, 1967, p. 38)

Confusion and fear in the transition between the past and present times are captured in "short and jerky sentences" and "long sentences." For example, the American John explains his country's failing to use the atomic bomb on Russia during WW11, saying, "But, we didn't. Why? Well, don’t ask me. I don't know. Perhaps we are naïve” (Achebe, 1967, pp. 45-46). Contrast the foregoing short sentences with the long sentence following immediately: "We still believe in such outdated concepts like freedom, like letting every man run his show. Americans have never wished to be involved in anyone else’s show. ...” (Achebe, 1967, p. 46) (The points of suspension are eloquent!). Noteworthy is all the sarcasm in that long sentence. In addition to creating distance and time, the long sentence also relates past and future fears. In Odili's soliloquy below (see Table 1), alternating short and long sentences describe his conflicting emotions during his first night at Chief Nanga's Bori residence:

Table 1

Sample Alternating Long and Short Sentences in A Man of the People

\begin{tabular}{|l|l|}
\hline 1. Long sentence: & $\begin{array}{l}\text { A man who has just come in from the rain and dried his body and put on dry clothes is more } \\
\text { reluctant to go out again than another who has been indoors all the time. }\end{array}$ \\
\hline 2. Long sentence: & $\begin{array}{l}\text { The trouble with our new nation-as I saw it then lying on that bed—was that none of us had been } \\
\text { indoors long enough to be able to say “To hell with it.” }\end{array}$ \\
\hline 3. Short sentence: & We had all been in the rain together until yesterday. \\
\hline 4. Long sentence: & $\begin{array}{l}\text { Then a handful of us-the smart and the luck and hardly ever the best-had scrambled for the one } \\
\text { shelter our former rulers left, and had taken it over and barricaded themselves in. }\end{array}$ \\
\hline 5. Long sentence: & $\begin{array}{l}\text { And from within they sought to persuade the rest through numerous loudspeakers, that the first } \\
\text { phase of the struggle had been won and that the next phase- the extension of our house-was even } \\
\text { more important and called for new and original tactics; it required that all argument should cease } \\
\text { and the whole people speak with one voice and that any more dissent and argument outside the door } \\
\text { of the shelter would subvert and bring down the whole house. }\end{array}$ \\
\hline
\end{tabular}

Notice that the narrative tone is not bitter, yet from another angle of vision it is angry, indignant, scornful, and enraged at the social injustice, the abject poverty of the common people, and the corruption of the so-called leaders (Achebe, 1967, pp. 86-87). At other times the criticism of society is direct, such as when Odili spits on the Minister before leaving him after their quarrel over his girl-friend Elsie: "What a country!” I said. "You call yourself Minister of Culture. God help us!” (Achebe, 1967, p. 74). Then, arrived back to Anata, Odili travels to Edna's home and advises her to leave old Chief Nanga for her own sake:

I want to give you a piece of advice — as one who has seen more of the world and as a friend. (...) You will be making a big and serious mistake if you allow anyone to rush you into marriage now. You are too young to be rushed into marrying, especially marrying a polygamist. (Achebe, 1967, p. 99)

Clearly, Odili cares about women and gender equality.

But, how do you convince the students that fiction, the imaginative, can be as real as nonfiction, the facts in society? What is the probability that what is learned in the classroom can happen in real life? Do characters truly reflect real people one may come across in real life? The teacher can seize the opportunity to teach "Verisimilitude" in this novel. How with a tremendous amount of details in relating events the author of $A$ Man of the People is able to show that facts observed in reality can be rendered imaginatively. These are events that

\footnotetext{
29 The impact of boycotting Josiah and his business is that: "Within one week Josiah was ruined; no man woman or child went near his shop. Even strangers and mammy wagon passengers making but a brief stop at the marker were promptly warned off. Before the month was out, the shop-and-bar closed for good and Josiah disappeared—for a while.”
} 
happen every day in the real society: violence, thuggery, hired assassins, killing, and maiming of political opponents during political campaigns, coups-d'état, womanizing of men in high offices, and promiscuity by young girls who crave money and big cars from sugar daddies. The powerful Nangas of this world reveal themselves through their own actions ${ }^{30}$ (Achebe, 1967, pp. 73-74). The narrative voice castigates them for using the people and misusing resources for services to the people. The local color and dialect extend the story, as in the instances where the narrative exploits pidgin, argot, and vernacular put into English (Achebe, 1967, p. 87). Ultimately, these realistic human conditions are also amenable to improvement and change through single, individual, and collective efforts, and the society as a whole. It is noteworthy and commendable that in making a powerful statement about warped human values and the question of reality versus illusion Achebe delicately manages not to allow fiction to turn into nonfiction or pathos into bathos.

If "suspense," there is in A Man of the People, it resides mainly in the long wait through the reading of the novel to find out how the novel will end. The dire irony is that Chief Nanga gets reelected, but he will not last another term as Minister of Culture, due to the social and political upheaval that shatters all his hopes. If the reader has not seen the inevitable end until it happens despite the first-person narrator's pointing to it, he/she has himself/herself to blame for mixing up reality and illusion.

Clearly, teaching and learning through literature in the classroom has untold benefits that censorship obliterates when texts are disqualified merely because of sex references, foul language, and other. Rob Jenkins reminds us of this in "The Forgotten Value of a Literature Course,” saying:

The study of literature incorporates many other disciplines. It certainly is valuable to learn about philosophy and religion. But the study of literature is the study of philosophy and religion. And politics. And history. And the arts. Not to mention gender, race, class, and a whole host of other topics that are both fascinating and relevant. In that sense, literature is the broadest and most encompassing of the humanities.

In that sense, literature is always relevant, whether written 10, 50, or 500 years ago. Perhaps, the most fascinating thing about studying literature, for me, is learning just how little people have changed, regardless of when or where they lived. That revelation, in turn, gives us a renewed appreciation for our common humanity, not only across cultures but across time ${ }^{31}$.

\section{Conclusion}

Clearly, studying literature in the classroom has more benefit for youth education than censorship. In studying Chinua Achebe's novel, A Man of the People, students grapple with the characters that provide a true reflection of people in society and their ways of thinking and acting. The mix of characters and the conflicts, politics, love and romance are valuable and help students to learn to generate their own ideas, question other people's arguments and assumptions, and understand that nothing should be taken at face value without proper analysis and interpretation. While searching for their individuality, they learn to eschew the native belief in their own superiority to other people, races, and cultures, or allow their ego to get in the way of pursuit of truth for the sake of saving face, or to resist change, or bow to stereotyping, conformity, and self-deception. Politics affords students the opportunity to learn to garner ability to move people, even as their youthful and idealistic

\footnotetext{
30 "Don't be childish, Odili," he said paternally. "After all she is not your wife. What is all this nonsense? She told me there is nothing between you and she and you told me the same thing ... But anyway I am sorry if you are offended; the mistake is mine. I render unreserved apology. It you like I can bring you six girls this evening. You go do the thing stay you go beg say you no want again. Ha, ha, ha, ha!”

${ }^{31}$ Rob Jenkins, Associate Professor at Georgia State University Perimeter College, writes in the Chronicle of Higher Education. Retrieved June 13, 2020, from https://community.chronicle.com/news/1896-the-forgotten-value-of-a-literature-course.
} 
eyes are opened to how evil and bad people can retain power in society. Then, they learn that so-called "modesty" could be pride in disguise. Furthermore, students are empowered to fight against oppression and social injustice, and struggle for gender equality. They learn to weigh the merits and demerits of democracy, and identify a true leader as the one that has integrity and discipline, respects the people, and sacrifices for them. He/she may not be the most popular with the common people, citizens that may not be in an appropriate position to make sound judgment. Finally, school districts, parents, and teachers must first consider the merit and value of a work of literature to the education of the youth before embarking on censorship.

\section{Recommendations}

From the foregoing conclusions, it is recommended that:

1. Students are given opportunity in the classroom to acquire lifelong learning values and norms that could change their lives in an increasingly interconnected world and larger ideas and truths in the society;

2. Exposure of students in the classroom to the culture and lives of people in literature can help them engage in their studies and appreciate other cultures, while learning to listen, read, analyze, write, and interpret situations as mirrored by the characters;

3. Teachers teach from the perspective of opening the students' eyes to see more that what is presented at face value, through analysis and interpretation of their findings;

4. Teachers guide students to learn to tolerate and better understand various conflicting, complex, and complicated views and opinions;

5. Students learn the foremost value of literature; opportunity to appreciate our common humanity across times and cultural spaces.

\section{References}

Achebe, C. (1967). A man of the people. (1966 hardcover). New York: Anchor Books.

Achebe, C. (2017). Chinua Achebe: The African trilogy (Foreword by Kwame Anthony Appiah). New York: Penguin Deluxe Classics Books Publishing.

Azodo, A. U. (2004). Masculinity, power and language in Chinua Achebe's Things Fall Apart. In E. N. Emenyonu (Ed.), Emerging perspectives on Chinua Achebe, Omenka the Master Artist: Critical perspectives on Achebe's fiction (Vol. 1, pp. 49-65). New Jersey: African World Press.

Azodo, A. U. (2019). Lagos Igbo Diaspora in selected writings by Flora Nwapa and Buchi Emecheta. Igbo Studies Review, 7 , 47-64.

Beauchamp, R. F. (Ed.). (1969). The structure of literature: A guide for teachers. Middletown, Connecticut (CT): American Education Publications (AEP).

Macionis, J. J., \& Vincent, N. P. (2017). Cities and urban life (7th ed.). New York: Pearson Educational Publishing.

Ohaeto, E. (Ed). (2003). Chinua Achebe: Straight from the heart. Lagos: The Stone Press Publishers.

Ronald, T. L. C. (1968). Of babies and bath water: A closer look at censorship. In R. F. Beauchamp (Ed.), The structure of literature: A guide for teachers (pp. 1-10). Middletown, Connecticut (CT): American Education Publications (AEP).

Ruggiero, V. R. (2004). The art of thinking: A guide to critical and creative thought (7th ed.). New York: Pearson Longman Publishing. 